\title{
Microvascular disease
}

National Diabetes Information Clearinghouse (NDIC)

\section{Definitions}

Blood vessels

Defined by National Diabetes Information Clearinghouse (NDIC)

Kidney

Defined by National Diabetes Information Clearinghouse (NDIC)

Protein

Defined by National Diabetes Information Clearinghouse (NDIC)

\section{Source}

National Diabetes Information Clearinghouse (U.S.). (2009). The diabetes dictionary. [Bethesda, Md.]: U.S. Dept. of Health and Human Services, National Institutes of Health, National Institute of Diabetes and Digestive and Kidney Diseases, National Diabetes Information Clearinghouse.

Disease of the smallest blood vessels, such as those found in the eyes, nerves, and kidneys. The walls of the vessels become abnormally thick but weak. Then they bleed, leak protein, and slow the flow of blood to the cells. 